\title{
RELATO DE EXPERIÊNCIA
}

\section{MIGRANTES ILEGAIS A VIDA E A LEI}

Margherita Bonassi*

D urante os anos 70 , os regimes militares que se instalaram na América Latina, especialmente no Cone Sul, apoiados em modelos econômicos concentradores, provocaram uma situação social dramática, com desemprego, inflação, custos de vida altíssimos, junto à violência, opressão, perseguições, medo e insegurança. Em consequência disso, milhares de exilados, refugiados, emigrantes, empurrados num sofrido êxodo forçado, espalharam-se pelo mundo afora.

O Brasil, dentro da geral recessão econômica latino-americana, parecia oferecer melhores condições e, por isso, muitos se dirigiram para o nosso país.

Em 1980, a CNBB-Conferência Nacional dos Bispos do Brasil, lançou a Campanha da Fraternidade sobre as migrações, com a finalidade de chamar a atenção a toda a sociedade para esta realidade dramática. Foi no final desse mesmo ano que comecei a entrar em contato com imigrantes latino-americanos, quando, na cidade de Porto Alegre/RS, os padres Missionários de São Carlos-Scalabrinianos, abriram o serviço sócio-jurídicopastoral no Centro Pastoral da Igreja N. Sra. da Pompéia. A partir de 1989, continuei este serviço na cidade de São Paulo, onde, desde 1977, atua o Centro Pastoral dos Migrantes N. Sra. da Paz.

\section{OS DESAFIOS DA LEI}

Nos primeiros anos da década de 80 , estimativas extra-oficiais apontavam a existência de aproximadamente 750 mil imigrantes ilegais no Brasil; desse total 100 mil residiam no Estado do Rio Grande do Sul, concentrados em sua grande maioria na capital - Porto Alegre. A maior presença verificada era de chilenos, argentinos e uruguaios, embora também fosse percebida a presença de bolivianos, colombianos, equatorianos, peruanos e, em menor número, também de outros países sul-americanos.

Mergulhamos logo numa realidade complexa, envolvendo todos os setores da sociedade. Causas políticas e econômicas, junto às culturais $\mathrm{e}$ sociais, entrelaçavam-se e confundiam-se no cotidiano desses imigrantes à procura de sobrevivência.

Os que fugiam de regimes opressores, depois de terem praticado algum tipo de contestação contra o governo - não raro vítimas de violências, torturas, perseguições - deixavam de improviso a terra, seus ente queridos e chegavam carregando consigo uma forte carga de sofrimento e dor, intranquilidade, medo e desconfiança, quando não perturbações de ordem psicológica.
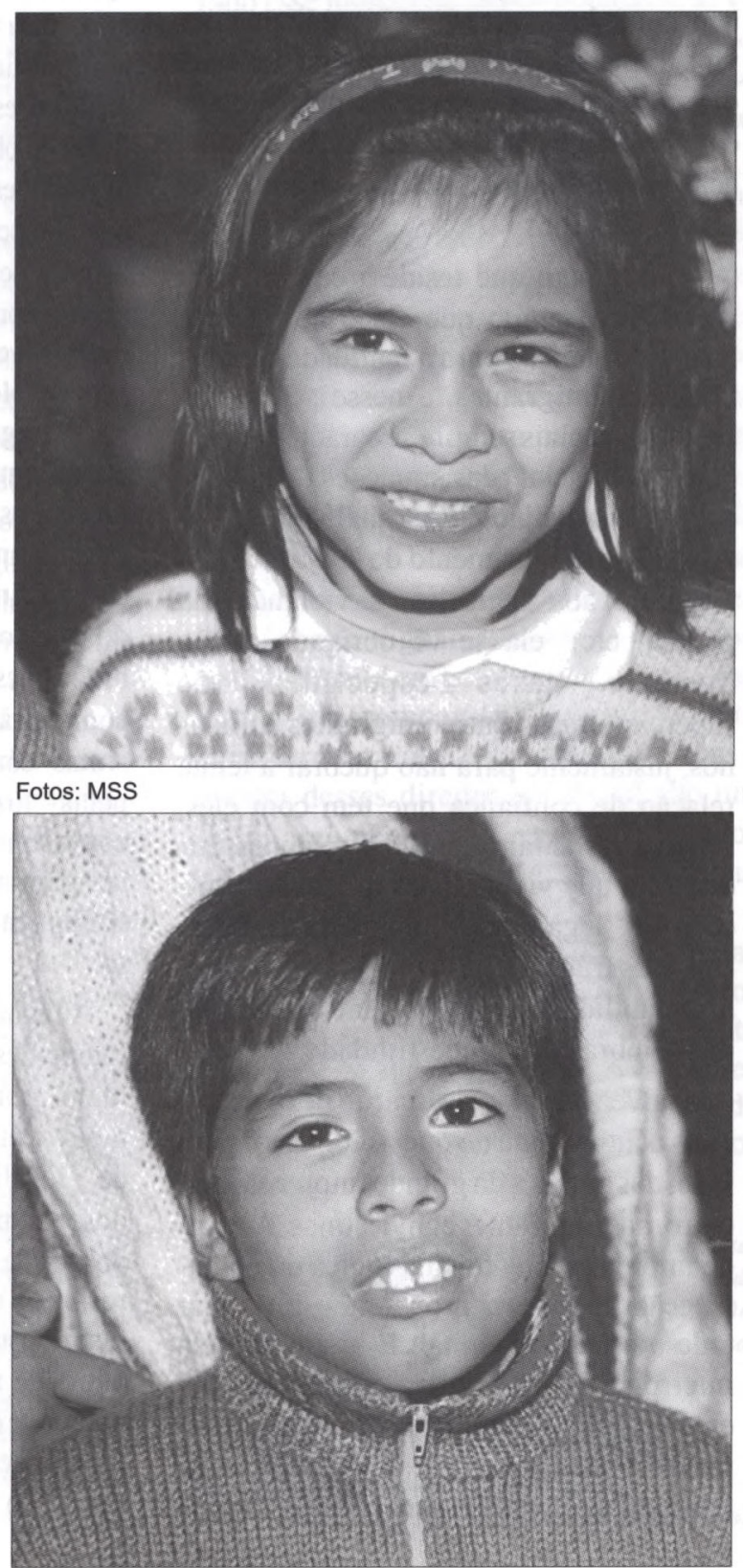
No começo de nosso trabalho, percebemos que muitos tinham medo de se identificar, desconfiados de tudo e de todos; outros optavam por obter informações apenas por telefone, evitando com isso o risco de se exporem publicamente. Foi o caso do Luiz, por exemplo, que fugido do Chile, ao ser encaminhado por nós até o Movimento de Justiça e Direitos Humanos, recusava-se terminantemente a ir sozinho pois, ao chegar no nosso Centro de Pastoral, havia visto, do lado de fora, na esquina, um policial fardado. Luiz estava tomado pelo medo.

Para auxiliar casos como estes, o Diretor do Movimento dos Direitos Humanos, Jair Krischke, atendia aos que o procuravam num pequeno bazar por ele gerido, numa das ruas mais movimentadas da cidade, procurando assim evitar controles.

Os que chegavam com o objetivo de pedir refúgio no ACNUR-Alto Comissariado das Nações Unidas para os Refugiados, eram encaminhados para o Rio de Janeiro, devendo emigrar para outro país que se dispunha a acolhê-los, pois o Brasil somente a partir de 1989 passou a aceitar refugiados "não europeus", quando eliminou a cláusula geográfica da lei dos refugiados.

A maioria, porém, preferia permanecer no Brasil, na esperança de que a situação política do país de origem pudesse mudar. Dentre esses, boa parte queria prosseguir até São Paulo onde, ouviram dizer, havia um bispo que através da Comissão Justiça e Paz e da OAB-Ordem dos Advogados do Brasil, amparava refugiados e, certamente, no anonimato de uma metrópole seria mais fácil passar despercebidos.

Para desencorajar a vinda e conter o número dos imigrantes no país, tinha sido sancionada a repressiva Lei do Estrangeiro ${ }^{\circ} 6815 / 80$, apresentada pelo Executivo como uma questão urgente, no dia 20.5 .80 e aprovada por decurso de prazo em 19.8.80, com a ausência da maioria parlamentar. O decreto que regulamentava a Lei saiu em dezembro de 1981; enquanto isso, valia o artigo 2: "Na aplicação desta lei se atenderá principalmente à Segurança Nacional" de acordo com o que diz a Constituição: "é de competência da União legislar sobre emigrações, imigrações, entrada, extradição e expulsão de estrangeiro".

Esta lei somava-se às demais na sustentação do regime militar, a exemplo da Lei de Segurança Nacional, do Decreto Lei 477, do AI-5, da Constituição anterior, da lei anti-greve, etc., segundo a qual todo estrangeiro era suspeito de subversivo assim como cada brasileiro era um possível inimigo interno do regime. A lei visava também impedir a entrada de padres estrangeiros, com medo de uma Igreja voltada para os oprimidos.

A manutenção de uma lei repressiva reforçou o arbítrio dos órgãos burocráticos do governo na prática de abusos. Era um sistema que formava cuidadosamente para o respeito às normas, mais do que às pessoas e que talvez esses funcionários não se dessem conta que também eles eram oprimidos pelo poder em nome do qual deviam oprimir. Contudo, em cada lugar havia um ou outro que se deixava tocar por situações dramáticas e encaminhava as pessoas para nosso serviço, criando assim situações contraditórias e conflitivas.

Mesmo os que tinham filhos e/ou cônjuge brasileiro, quando descobertos em situação ilegal, recebiam o "convite" para deixar o país e o que parecia, segundo a lei, uma permissividade, provocou em muitos desilusões. A lei era desrespeitada por quem se orgulhava de cumpri-la em seus detalhes. Sem direito à defesa, multados, tinham que deixar espontaneamente o Brasil, com viagem custeada por eles mesmos, obrigados pela lei a separar-se da família.
“Tenho dois irmãos na Argentina... năo sei se ainda estăo lá, nâo consegui encontrá-los, pois tive que fugir. Uma noite, voltando para casa, me avisaram que tinham arrombado 0 meu quarto e vasculhado em cada canto. Tive medo e vim para cá, somente com os documentos. No Chile ficou a mâe com minha irmå. O pai... o pai faleceu... faleceu num acidente misterioso... nunca soubemos a verdade... Eu năo pude mais continuar a faculdade... Começaram aemigrar os meus dois irmåos... depois eu... Se eu pudesse trabalhar e terminar os estudos... Nunca será possível ter o documento? Com os bicos é uma briga para a sobrevivência..." (Escobar, 20, chileno)

Numa tarde, no começo do ano de 1981, um casal uruguaio, com duas crianças - um nenê e uma menina de três anos chegou transtornado. No rosto, o medo; no peito, a dor e a saudade...

De madrugada, um amigo os havia avisado da iminente chegada da policia. Deveriam fugir! Pegaram apressadamente umas coisas e com os dois filhos no colo, partiram deixando tudo. "Nấo nos despedimos nem de nossos familiares!", dizia ela. O amigo levou-os de carro até uma cidade próxima, onde esperavam o ónibus que os levaria até a fronteira; dali outro ônibus até Pelotas e outro até Porto Alegre, onde amigos os esperariam na rodoviária.

Mas o enorme atraso sobre a hora marcada, fez com que houvesse um desencontro. Na rodoviária de Porto Alegre, cada pessoa parecia-Ihes um policial. Estava presente, na memória deles, o rumuroso sequestro de Lilian Celiberti e Universindo Diaz, em 1978, por militares do Uruguai, com a participaçăo de policiais brasileiros. Dirigiram-se então, de táxi, paraa Cúria Metropolitana, pedindo ajuda ao Bispo, que nos ligou e os encaminhou para nós. O nenê dormia tranquilo no colo da máe e a menina apertava um ursinho no colo, como para protegê-lo. Abrigamos a família num apartamento de um hospital de religiosas, até conseguirmos a passagem para $\circ$ Rio de Janeiro, onde pediram refúgio politico e de lá, quando os papéis estivessem prontos, embarcariam para a Suécia, como nos escreveram depois de alguns dias.

"No puedo volver a Chile", dizia angustiado Juan, pedindo assessoria jurídica. llegal, traído pelo sotaque enquanto pagava um café no caixa de um bar, foi descoberto por um agente da Policia Federal que estava na fila. Juan tirou do bolso um papel dobrado e nô-lo entregou dizendo: "Ustedes no pueden hacer algo?" Ao pegar o papel tâo conhecido, 0 auto de infração e autuação, vimos logo a sua assinatura embaixo da frase que nunca teríamos desejado encontrar: "Declino do direito de apresentaçáo de defesa dentro do prazo legal e declaro incontestável o presente auto". O prazo legal de cinco dias, contemplado pela lei, possibilitava a pessoa defender-se alegando os motivos da ilegalidade. Juan năo quis deixar o país, continuou, ilegal, a se esconder, na esperança de um dia poder caminhar, como qualquer pessoa, à luz do sol, sem saltar de endereço a cada possível ameaça de batida sobre clandestinos. 
Acompanhar os migrantes junto aos órgãos públicos tornava-se necessário em certas situações, de acordo com o diretor do Movimento de Justiça e Direitos Humanos. Mas não demorou a vir a intimação de não imiscuirnos com estrangeiros porque, como dizia a Lei do Estrangeiro: "quem oculta ilegais e clandestinos tem a mesma pena deles", com a proibição de nossa presença junto aos mesmos nas idas à Polícia Federal.

A despeito do rigor da Lei, os imigrantes continuavam chegando. Os motivos que os faziam deixar sua terra pareciam mais fortes do que as barreiras da Lei.

A permanência definitiva, com direito ao trabalho remunerado, foi concedida praticamente aos estrangeiros com cônjuge brasileiro (até 1985 eram necessários cinco anos de casamento) e/ou com filho(a) brasileiro(a). Os imigrantes que chegavam com o visto de turista, geralmente válido por 90 dias, com proibição de exercer atividade remunerada, eram condenados a viver ilegalmente, pois não podiam preencher os requisitos exigidos pela lei. Ilegal é todo estrangeiro que tem o visto vencido; clandestino, ao invés, é quem entra no país sem visto: os dois são considerados infratores pela mesma Lei que os obriga à ilegalidade.

Antes da Lei de 1980 era possível transformar o visto de turista em permanente, então os que chegavam desconsideravam as dificuldades da lei, pois o Brasil para eles era o país do futuro, do progresso e sobretudo de maior liberdade e pensavam que se podia achar sempre um jeito para se inserir no novo meio. Muitas vezes, porém, logo ao chegar, especialmente os que se mostravam um pouco desorientados, eram assaltados na rodoviária, roubados ou enganados e explorados. Acontecia também que ao achar serviços provisórios, muitos ilegais não eram pagos, ficando impossibilitados de reclamar por medo de serem descobertos, e sem recurso algum. Malandragens, às vezes, aconteciam também entre os próprios migrantes, especialmente entre os que visando o lucro, esqueciam-se de ter passado pelo mesmo caminho, gerando certa desconfiança e intranquilidade entre os próprios imigrantes.

Depois dessas experiências negativas, se no começo quase ninguém queria voltar frustrado para sua terra, constatando porém o aumento das dificuldades pela sobrevivência e encontrando-se a dormir na rua, na rodoviária ou no albergue dos pobres, alguns resolviam retornar para seu país, outros continuavam permanecendo, na teimosia e na esperança do impossível que poderia acontecer, como a mudança da lei ou a anistia. Entretanto, novos imigrantes continuavam chegando.

\section{ENTRAVES BUROCRÁTICOS}

A tramitação do processo de permanência exigia taxas elevadas e um número exagerado de documentos, dentre os quais os mais difíceis de se obter eram a Certidão de Nascimento, o Atestado de Antecedentes Criminais do país de origem, (os dois traduzidos em português e legalizados pelo Consulado Brasileiro), e a promessa de trabalho por parte de uma empresa brasileira. Eram excluidos, a priori, os que tinham problemas políticos em sua terra, os pobres e os que sobreviviam de trabalhos provisórios, obrigados a permanecer na clandestinidade, sem identidade legal, sem existir para a sociedade, mesmo tendo direito à cidadania. Somente com o Parecer $n^{\circ} 218$ / 85 de 5.11 .85 , foram dispensados os últimos dois itens.

Em contrapartida, investidores e profissionais especializados sempre
"Mesmo trabalhando, não dava para viver, fiquei desempregado e tivemos que sair..." (Luiz, com esposa e filho, uruguaios)

"Fui obrigado a sair... respira-se o medo, a perseguição, a violéncia, a opressão, a arrogáncia... Eu ia todos os dias para - trabalho, porém não sabia se à noite voltava vivo para casa... Vi matar uma criança na rua, somente porque chorava de medo... Não podia mais aguentar... Atravessei a Argentina... não encontrei trabalho... Vim para cá, estou na rua. Faz uns dias que como o que me dão, pedindo. Estou experimentando o que quer dizer ser estrangeiro. Por que tantas barreiras para uma pessoa que somente quer trabaIhar? Onde está a fraternidade latino-americana? Como posso viver sem documentação? Eu não sou ninguém!" (Pedro, 23, chileno)

"Eu sal do Chile porque meu pai perdeu o emprego, não concordando com o regime. Eu sou o mais velho, estava estudando mas não pude mais... Não seicontar os bicos que já fiz, eu que nunca trabalhei... Aproxima-se o Natale não dá para ir lá, a passagem é tão cara! Nunca tinha experimentado o que quer dizer não ter o que comer, pedir trabalho como esmola... (Hector, 19, estudante de medicina).

Carlos estava conversando tranquilamente na hora do almoço com amigos no parque na Redenção, quando foram descobertos pela Policia Federal. Eraa segunda vez. A pena, neste caso, é multa duas vezes superior à anterior e deportação imediata. A polícia embarcou-o no ônibus rumo ao Chile. "Eu estava desanimado e humilhado, mas na primeira parada, ao descer com os outros, não sei, me senti livre... Dirigi-me rapidamente para o centro da cidade, e mais tarde voltei de carona para cá. Parecia-me ser um delinquente e qual é meu crime? Querer trabalhar, querer ficar aqui, eu gosto do Brasil... por que estas leis?... Se salsse a anistia!! Seme procurares, fala com Ivan, ele sabe ondeme encontar, eu não sei para onde vou, mas não fico no mesmolugarmais de uma semana... desta vez estarei preso."

"Não achei nenhum bico mais... faz dois dias que vivo na rua, sem comer... eu pensava que aquifosse diferente... Hoje, na praça, vendo um homem passar com pão, queria roubar aquele pão. Nunca, na minha casa, no meu pals, eu tive esses pensamentos loucos... Ser acolhido é como começar a ter esperança, a seguir em frente, a sentir-me alguém... a sentir Deus mais perto". (Roberto, 23, técnico eletrônico, uruguaio). 
foram bem-vindos, a fim de facilitar a entrada do capital estrangeiro. Para eles está à disposição o setor jurídico da grande empresa que os contrata providenciando os papéis necessários. As relações de mercado estabelecem assim fronteiras, mantendo os pobres na clandestinidade para que continuem sendo caso de polícia e passíveis de deportação.

Não tendo o documento que dá acesso a um trabalho com registro, conforme sua profissão, muitos foram os migrantes que assistiram à própria desqualificação profissional. Mesmo para os que, com enormes dificuldades, conseguissem dar entrada ao pedido de permanência, o documento era entregue depois de um longo prazo, sendo que o processo ia para Brasília para ser examinado a fim de averiguações detalhadas onde passava a engrossar as enormes pilhas de papéis da burocracia. Depois de anos, o interessado recebia deferimento para se apresentar à Polícia Federal: mais uma vez era-lhe exigida outra lista de documentos e outra taxa, a fim de retirar o documento tanto esperado e sonhado. Em muitos casos o deferimento não era comunicado, como de praxe, cabendo ao interessado acompanhar diariamente o Diário Oficial da União para ver se encontrava seu nome, coisa não acessível a todos; com isso, muitos perderam o prazo e tiveram que recomeçar de novo o processo de permanência.

Neste entretempo de espera do documento, os migrantes recebiam o protocolo, comprovante da entrada do pedido de permanência e de sua estadia legal, porém continuavam sendo proibidos de exercer trabalho remunerado: contradição da Lei, que exige a comprovação por parte do estrangeiro da capacidade de manutenção da família para apresentar o pedido de permanência. Obrigados a aceitarem qualquer emprego ou subemprego, explorados em horários excessivos de trabalho, com moradia e comida precárias, mal ou nem pagos, eram os primeiros a serem demitidos em caso de recessão, sem contar com a impossibilidade de reclamar ou apelar à justiça, pois se descobertos trabalhando como ilegais eram multados e deportados.

Os migrantes, logo que conseguissem obter o documento definitivo, procuravam dar entrada ao pedido de "Reunião Familiar" para parentes ainda ilegais, (filhos nascidos no exterior, pais, avós, irmãos e menores dependentes). A partir de 1987, o Ministério de Relações Exteriores em Brasília não aceitou mais estes pedidos enviados diretamente pelos interessados, mas somente através do Consulado Brasileiro no país de origem ou de um país limítrofe. O Consulado enviaria os pedidos para Brasília, que após análise, poderia conceder o visto permanente enviando o deferimento diretamente para o Consulado. Portanto, para esse pedido eram necessárias duas viagens para fora do Brasil: a primeira para entregar o pedido e a segunda para retirar o visto e fazer o exame médico (somente com o médico indicado pelo Consulado). Como aumento da taxa deste visto para US\$120,00, somado aos custos com viagens, passaporte obrigatório, exames médicos, etc., tornou-se muito difícil a tramitação. Em certos casos, como decorrência, surgiam tensões familiares e até separações forçadas. Somente com a Resolução $n^{\circ} 22$ de 16.10.91, simplificar-se-ão os trâmites: atualmente, os pedidos de reunião familiar são feitos através da Polícia Federal da região de residência, sempre que com o visto não vencido.

Normalmente, a maioria dos migrantes que entrava com visto de turista, cuidava de ir até a fronteira antes do vencimento dos 90 dias, para entregálo aos agentes de fronteira e retornar com um novo visto de até 90 dias, para depois deste prazo se encontrarem na mesma situação. Uma viagem que,
"Fiquei preso uma noite por ter sido encontrado sem documentos. Tiraram-me os poucos pertences... não entendia nada do que o policial me dizia... Agora passo a noite na rodoviária..." (Carlos, 20, mecånico, argentino).

"Eu encontrei emprego, mas todos me pedem a Carteira Profissional, onde posso consegui-la? Quero só uma permissão de trabalho, como me sustento? Na pensão pegaram minha bolsa e não vão devolvê-la até eu não pagar". (Alberto, argentino)

Oscar, argentino, 20 anos, ainda abalado pela guerra das Malvinas em que quase morreu congelado nas águas do mar, se não fosse salvo pelos "inimigos" ingleses, que o resgataram no navio e cuidaram dele, dizia:

"Não sei se é melhor morrer na guerra ou morrer de fome.. faz quatro dias que não como... Uma guerra estúpida e inútil... não consigo mais ficar lá... vi morrer o meu amigo... e aqui, não tem lugar para um estrangeiro como eu... o que faço? Quero só trabalhar, mas me pedem o Modelo 19..."

"Faz quatro anos que começamos a juntar os papéis para o pedido de permanéncia definitiva: Daniel foi para o Uruguai pedindo a Certidão de Bons Antecedentes, que a entregam somente depois de 30 dias e ele tinha que voltar lá para buscá-la, mas sempre nos encontramos em dificuldade económica; a Certidão vencia e pediamos outra, e isso por trés vezes. Ele não quer saber mais de papéis. Eu achava que ele criava desculpas quando falava dos entraves burocráticos e muitas vezes brigamos por causa disso... Não entendo o porqué destas complicaçóes, já temos trés filhos!" (Jacira, brasileira, esposa de Daniel, uruguaio). 
com o decorrer do tempo, foi se tornando sempre mais difícil. Os agentes de fronteira, a fim de desencorajar as entradas, foram diminuindo progressivamente os prazos de validade do visto de turista, especialmente aos suspeitos de quererem emigrar definitivamente, sendo desrespeitados e até objetos de abusos.

Os imigrantes que passaram pelo Serviço Sócio-Jurídico, no ano de 1987, receberam o visto de turista com os seguintes prazos: de 5 a 15 dias, $39 \%$; de 20 a 30 dias, $49 \%$; de 60 a 90 dias, $12 \%$. Depois deste ano, somente $2 \%$ conseguiu permanecer com o visto em dia. Quando indagamos à Polícia Federal se a redução dos prazos não ia contra a lei, ouvimos o seguinte: "Estão somente cumprindo a lei, ela diz até 90 dias e não 90 dias."

Então, pela falta de perspectiva de uma possível futura permanência, e para sair da fome e sobrevivência, mesmo com medo, alguns diziam ser "obrigados a driblar a lei para ficar dentro da lei", através de registros de filhos "fantasmas" ou "casamentos" efetuados somente no papel. Nestes casos, exploradores e aproveitadores, que com promessas ilusórias da obtenção fácil e imediata do documento e com altos ganhos devido a "amigos" em postos estratégicos, ofereciam seus "serviços profissionais", às vezes sumindo com o dinheiro adiantado sem deixar endereço ou continuando a prometer cada dia para o "amanhã", até cansar o requerente interessado. Eram, porém, "saídas" que deixavam consequências ainda mais angustiantes.

A fim de evitar falsificações, foi introduzida a sindicância, através da qual um agente da Polícia Federal controlava na habitação dos migrantes se havia convivência com o cônjuge e os filhos brasileiros e se efetivamente o estrangeiro os mantinha. Ocorre, porém, que os migrantes, pela provisoriedade em que viviam, mudavam seguidamente, acompanhando as mudanças do emprego e os aluguéis mais baixos. Quando não encontrados no endereço, o processo era enviado para Brasília com parecer negativo e o Ministério da Justiça indeferia e arquivava os papéis. O estrangeiro podia pedir o desarquivamento do processo, mas a burocracia ia se multiplicando enquanto ele era obrigado a ficar mais anos sem poder trabalhar legalmente.

O trabalho de acompanhamento dos processos em Brasília foi e continua sendo de grande importância para os migrantes, que podem saber notícias certas sobre seu andamento. Alguns imigrantes que viviam em Brasília, auxiliaram nos primeiros anos acompanhando os processos nos Ministérios, até contar com a valiosa assessoria do CSEM-Centro de Estudos Migratórios Scalabriniano de Brasília, que se coloca gratuitamente à disposição para os contatos com os Ministérios a fim de agilizar os trâmites.

Mas a sindicância, em muitos casos, continuava se revelando uma armadilha dolorida para os migrantes: os parentes ilegais encontrados eram multados e intimados a deixarem o país. Por isso, a visita de desconhecidos provocava inquietação nos imigrantes ilegais, por medo de se encontrarem diante de um policial.

A situação dos ilegais tornava-se mais complicada quando, por graves motivos familiares, eram obrigados a viajar de improviso para suas terras. As empresas de transporte eram proibidas, pela lei do estrangeiro, de emitir passagem a ilegais e clandestinos; então, estes não tinham outra opção que a de se apresentarem à Polícia Federal, para serem multados e receber o auto de infração e autuação, com prazo de oito dias (ilegais) ou três dias (clandestinos) para deixar o país.

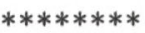

Alex, boliviano, ilegal, casado com brasileira, estava feliz, porque dentro de pouco tempo iria nascer o primeiro filho e além disso, uma grande empresa havia prometido registrá-lo, bastava somente apresentar o Modelo 19. Foi então na Polícia Federal. O filho iria nascer dentro de um mês e queria já preparar os papéis. Mas recebeu multa e prazo de oito dias para deixar o país. A defesa, pedindo o cancelamento da multa, năo foi aceita. Alex decidiu ir para a Bolívia buscar o Atestado de Bons Antecedentes: as taxas para este documento, junto à tradução e a legalização eram mais caras do que a multa. Pôde pagar somente as Certidões através de empréstimos. Ao regressar ao Brasil, conseguiu entrar clandestinamente, depois de várias tentativas arriscadas. "Eu fugia do controle como um criminoso... o medo me dizia de desistir, mas pensando na Mari e no nosso filho tentava arriscar..." A esposa já tinha dado à luz e não morava mais no apartamento. Alex perdeu a possibilidade do trabalho e foram para uma pensão e dali para a periferia. Serviços provisórios năo eram suficientes e Mari começou a trabalhar numa lancheria, enquanto ele cuidava do nenê. Quando fui visitálos, encontrei Alex trocando fraldas e para preparar a mamadeira foi buscar água nos vizinhos, porque não havia na sua casa. "Os vizinhos me olham mal, dizem que eu não quero trabalhar, que me faço manter por Mari, não entendem minha situação... Quando vai sair a anistia?"

Alex era engenheiro químico, mas fazia qualquer serviço que se Ihe apresentasse, assim como Jorge, peruano, arquiteto, fugido do Peru por motivos políticos. Jorge não podia provar as perseguições e não recebeu amparo do ACNUR; tornouse ilegal e sobrevivia vendendo pequenos brinquedos na rua. "Não sei mais quem sou, Jorge não é meu nome... já tive muitos..."

"Vieram em casa para controlar se nosso filho existia e vivia conosco... Encontraram minha mãe que cuidava dele. Ela estava como ilegal. Não tinha saido do país quando recebeu a multa. Não tínhamos dinheiro. Levaram-na para a Polícia Federal, para registrar a autuação e a intimação de deixar imediatamente o pais; a companharam na rodoviária e a embarcaram no ônibus para o Chile... Não consideraram a idade, 70 anos, e nem deu tempo para fazer a mala... Agora não pode voltar até não pagarmos a multa; nunca conseguiremos, cresceu demais, com juros e correção monetária.. O documento dela só se pode fazer quando eu receber a permanéncia... Eu tenho protocolo, mas não serve... O pai morreu e fomos buscá-la. Eu e meu irmão, que ainda éilegal, queriamos tanto que ela ficasse conosco! Que incomodação dava?" (Carlos, 29, chileno).

"Eu trabalhava numa fábrica... As Forças Armadas vieram de repente e prenderam todos do meu Departamento. Fomos levados ao estádio... Ficamos quatro dias, quase nada para comer, sentados, com a proibição de falar e de se mexer... Depois de alguns dias, vendaram nosso olhos e fomos levados não sei para onde. Pegou-me o medo de não saber o que me inia acontecer... O interrogatório, no começo com exagerada cortesia, foi feroz... enquanto me batiam, eu sempre vendado, gemia e estava certo de não sair dali.. comecei a pensarna minha familia, na namorada e a rezar. Mas me soltaram.

Não consegui mais trabalho... Aqui não aguentei sozinho, avisei a ela que preparasse os papéis e fuilá para casar... Eu tenho o Documento porque entrei antes da lei atual, mas minha esposa está como turista. O Consulado Brasileiro em Santiago falou que a tramitação era muito fácil, mas a Polícia Federal disse que Marta tem que sair do país para fazer o pedido no Consulado Brasileiro, não é possivel, chegamos faz duas semanas..." (Miguel). 
Muitos eram os chilenos que chegavam; entre 1973-90, de fato, calculase que 1.200.000 chilenos abandonaram seu país, pelo crescente desemprego, que alcançou $31,3 \%$ em 1983 , e pela situação social degradante que se criou: $40 \%$ de pobres num país que tinha uma longa tradição democrática e uma forte identidade étnica e cultural.

Calcula-se em mais de 500 mil os jovens que emigraram do Uruguai em busca de um futuro promissor, uma verdadeira hemorragia sobre 2,7 milhões de habitantes, "um pais de velhos que condena ao exilio seus jovens" (Galeano). Um país que era chamado a Suiça da América, pelo padrão de vida e cultura democrática e que viu a degradação social com o advento da ditadura (1973-1985), "treze anos de terror, torturas, assassinatos $e$ desaparecimentos; quase cada familia teve um parente na prisão", diziam os migrantes.

Para os que não têm filhos ou cônjuge brasileiro, mesmo integrados há anos à vida do país, continuam sendo penalizados não podendo legalizar sua situação jurídica. Em duas oportunidades foi concedida esta possibilidade, em 1981 e 1988, com as leis de "anistia". Poder-se-ia dizer que eles não souberam aproveitar, mas vários fatores contribuíram simultaneamente para que a maioria dos ilegais permanecesse na mesma situação: o prazo exíguo; a fraca divulgação; as taxas elevadas; as exigências requeridas muitas vezes de maneira diferente por cada pessoa; e, por parte de muitos ilegais, houve retração, por medo que o registro fosse a senha para sua expulsão, como diversos já tinham experimentado. Na realidade, em 1981, somente cerca de 27.000 ilegais, no Brasil, conseguiram o documento.

Os Centros de Pastoral dos Migrantes em São Paulo e Porto Alegre, lutaram em 1983-84, e com sucesso, para que fosse aprovada no Congresso a proposta de lei que autorizava a transformação para permanente da carteira provisória de dois anos, improrrogável, concedida pela anistia de 1981. Um abaixo-assinado, no qual os imigrantes participaram ativamente, acompanhava a proposta de lei, a fim de impedir a deportação dos que iriam ficar ilegais após o vencimento da carteira provisória. As assinaturas podiam ser exclusivamente de brasileiros, pois estrangeiro, mesmo com documento legal e com muitos anos de residência, não pode ter direitos políticos.

Em 1988, a estimativa de ilegais era ainda maior. Pela anistia (Lei 2481 de 3.10 .88 ) somente cerca de 30.000 conseguiram o documento provisório, válido por dois anos, prorrogável por mais dois, desde que cumprissem as exigências determinadas pela Lei, entre as quais trabalho registrado em carteira. E, finalmente, antes do término do prazo do segundo documento, podia-se requisitar o documento de permanência definitiva.

Muitos, porém, foram os entraves burocráticos, que impediram renovar o documento a um considerável número dentro desses 30.000: o mais injusto foi a grande demora por parte da Polícia Federal em emitir o segundo documento provisório, que era entregue aos imigrantes absurdamente já vencido, sem possibilidade de requisitar a transformação em permanente, porque necessitava fazê-lo antes do vencimento!

Estes imigrantes caíram de novo na ilegalidade, pela armadilha de normas legais arbitrárias e injustas. Quantos ficaram inconsoláveis diante da situação de estarem irregulares no país do dia para a noite e, posteriormente, verem seus filhos banidos das escolas! De nada valeram as reclamações e os pedidos de reconsideração dos processos. Todavia, esta reivindicação está se concretizando agora, fruto da teimosa insistência de advogados latinos e brasileiros, assessores da Pastoral dos Migrantes, nos diferentes Centros dos Migrantes do país, com o apoio dos CSEM/Brasília, analisando caso por caso.
"No Uruguainão há trabalho, não háfuturo... Faz sete meses que estou no Brasil. A cada 90 dias vou à fronteira para renovar o visto de turista... cada vez, quando o policial da fronteira olha o documento e depois olha para mim, o coração bate forte... cada vez um medo a menos. (Walter, 20 anos).

"Lá na fronteira, em Uruguaiana, deram-me somente dez dias de prazo de turista. Com tudo o que eu fiz para arrumar dinheiro para esta viagem!... Obrigam-me a ficar ilegal... Pediram-me trezentos dólares em troca de 90 dias de prazo e me revistaram vulgarmente dizendo que não queriam vagabundos e traficantes..." (Ernesto, Chileno).

"Eu pensava que a situação iria mudar logo e não quis emigrar para o Canadá, em 1980, junto com meu primo, depois de presos por protestos na Universidade. Acreditava no ideal de justiça e de paz. Meu primo escrevia que lá havia boas possibilidades de carreira. Mas eu me obstinava a esperar... fui obrigado a fugir, quando me encontraram a cantar músicas de protesto. Cheguei aqui somente com a identidade, faz dois anos... ainda sem documentação. Estou sobrevivendo fazendo artesanato, nunca fiz na minha vida.. estou cansado de ter que me esconder. Mas que vida é a minha? Não posso estudar, não posso trabalharlegalmente. Já tenho 26 anos. A pessoa parada não progride, retrocede na vida. Para que me serviu esta longa espera? Estou com as mãos vazias... Gosto de uma moça daqui, mas que futuro posso oferecerpara ela? Eu sou umilegal, nåo conto nada..." (Cláudio, chileno).

\footnotetext{
"Faz quase dois anos que estou no Brasil. Eu morava perto dos militares e a cada semana presenciava mortes... Decidi ir embora, em busca de paz, no dia em que morreu um amigo meu... Eu estava correndo ao lado dele, no meio daquela confusão... e ele caiu... Peguei o trem para Santos, onde pretendia entrar na marinha. Na viagem encontrei trés rapazes, também bolivianos, músicos, que vinham para o Brasil. Em São Paulo, eu quis me despedir, eles insistiram para eu ficar e descansar. Fiquei... sou do conjunto. Viemos para cá para fazer conhecer a nossa cultura... Mas tenho a carteira provisória da anistia, vai vencer em fevereiro... não vão prorrogá-la mesmo? (Victor, 20).
} 


\section{CULTURA E SOLIDARIEDADE}

Mesmo que forçados a saírem de suas terras por causa de sistemas sóciopolíticos injustos e a viverem "presos em liberdade" pela rigidez da lei, a dimensão da festa, como expressão da cultura, acompanha os imigrantes em cada passo, de forma espontânea e como algo essencial para suas vidas. É notório que nos anos 80 , muitos movimentos populares, grupos de base, órgãos diferentes, fermentaram a sociedade fazendo crescer 0 anseio pela vida, por justiça, pela democratização. Também os imigrantes constituíramse em atores sociais à sua maneira, mesmo que a Lei não os considerasse $\mathrm{e}$ sobretudo os proibisse da prática política, como se esta dimensão fosse algo separado da vida.

A expressão da cultura refletia publicamente os questionamentos e desafios cotidianos da vida política do país de origem e do país de acolhida, constituindo-se num canal de comunicação capaz de fazer ouvir a sua voz e a dos que vivem oprimidos e sem direitos. De fato, o desenraizamento, o medo, a exclusão, não impedem que as lágrimas, as lutas, as lembranças, a vida, sejam acompanhadas pelo canto e pela música.

Foi precisamente através da música que em 1981, reuniu-se o primeiro grupo no Centro de Pastoral de Porto Alegre, composto por integrantes de diferentes nacionalidades, muitos deles ilegais, com o objetivo de organizar um show para os que mais precisavam. "América sin fronteras" era o nome do grupo, traduzindo um programa de vida: solidariedade, integração e cultura.

Através de inúmeros contatos, divididos em pequenas comissões, uma rede de relações crescia a cada dia, como bola de neve, uma rede invisível que se espalhava agindo como fermento na massa. Os que iam tomando conhecimento do grupo, com alegria a ele se somavam.

Também o serviço aos migrantes foi possível graças a inúmeros contatos, relações, tentativas junto a instituições, órgãos, empresas, consulados, famílias e nos diferentes ambientes, para uma ajuda cotidiana concreta: advogados latinos auxiliavam na interpretação da lei; empresários emitiam as "promessas de trabalho" necessárias ao pedido de permanência; lancherias ofereciam almoço aos mais necessitados; uns hotéis reservavam quarto para emergências; famílias e instituições acolhiam migrantes; diversas pessoas, também entre os mesmos imigrantes, entregavam roupa, comida e dinheiro para as situações mais difíceis, através do projeto "Comunhão e Participação: Migrantes ajudam Migrantes". Jovens de diferentes paróquias de Porto Alegre ajudaram no trabalho de campo numa pesquisa entre 300 famílias imigrantes latino-americanas, com a assessoria do Centro de Estudos Migratórios de Porto Alegre, para uma leitura da realidade a fim de crescermos num serviço sempre mais próximo das pessoas.

"La música no tiene fronteras y como la música queremos vivir nosotros, hijos de esta tierra, la Patria Grande..." disse Eduardo, uruguaio, apresentador do $1^{\circ}$ Show "Canta América Sin Fronteras", quando, de repente faltou a luz. Este show, que continuou à luz de um lampião de gás, permaneceu por muito tempo como símbolo da vida que quer brilhar no coração de cada pessoa, de cada povo e caminhar com esperança e coragem, nas trevas dos regimes opressivos. O charango, a quena, a zampoña, o bongo, o violão espalhavam seus sons típicos e a música penetrava em todos despertando saudade, a típica saudade dos migrantes, indefinível e sempre presente, que faz despertar o desejo de liberdade, de fraternidade, de harmonia. Nunca faltava o conjunto dos amigos brasileiros com seus perfeitos "chorinhos".

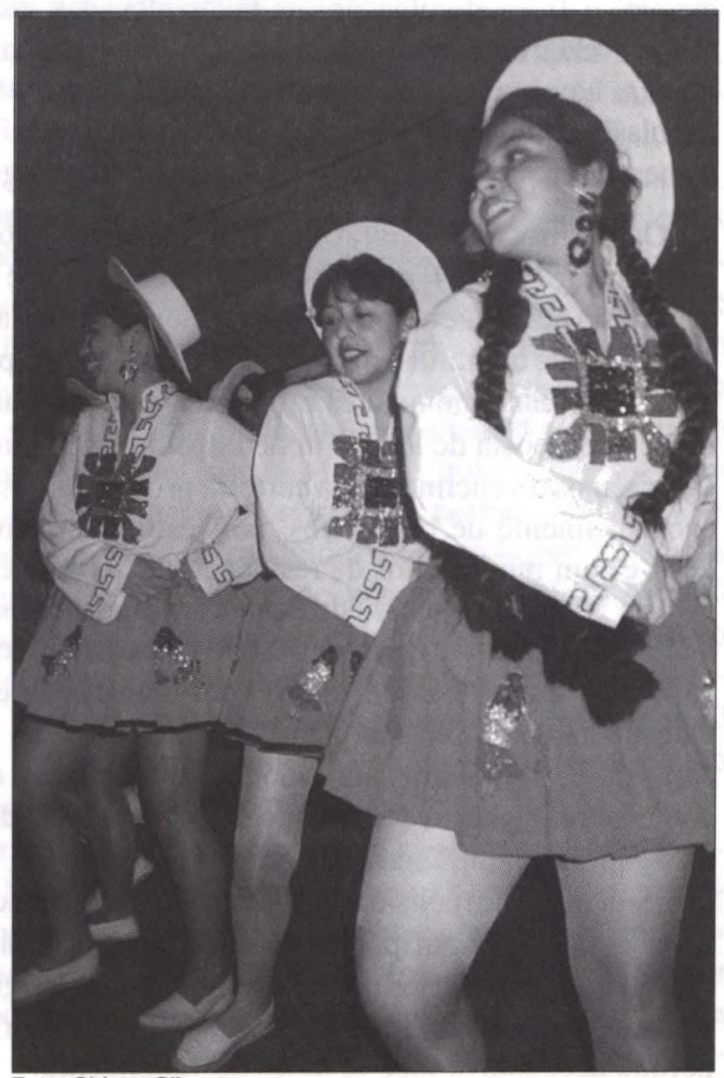

Foto: Sidney Silva 
Outros shows seguiram-se e continuaram se realizando junto a outros eventos culturais como Peñas e Fogón Criollo, entre participantes de diferentes nacionalidades, com debates e trocas de experiências de vida, descobrindo juntos a "vocação especifica do migrante, a de fazer das fronteiras dos povos muros abertos, pontes de unidade e paz", como dizia Rosa, uruguaia.

Estes eventos tornavam possível aos migrantes mostrarem um pouco da cultura, do espírito, dos valores e da riqueza humana de suas terras, de experimentar a emoção de poder cantar cantos proibidos em seus países, de tornar público seu amor e sua dor pela pátria, que na emigração se alarga na dimensão de América Latina e do mundo inteiro e que, talvez, nada como a música e a arte conseguem transmitir.

\section{MIGRANTES NA ILEGALIDADE HOJE}

Praticamente todos os regimes de governo mudaram, mas a migração continua nos dias atuais, na América Latina e no mundo inteiro, antes, com dimensão planetária, "tornando-se um dos mais complexos e dramáticos acontecimentos da história” (João Paulo II). Estão se globalizando, no mundo, as leis migratórias discriminantes e excludentes, enquanto, no Brasil, continua vigorando o mesmo rigor da Lei do Estrangeiro de 1980.

Se ficarmos no "espírito" da lei, feita com objetivos políticos, vemos cada estrangeiro como alguém que incomoda, que rouba o trabalho dos nativos, vemos o outro como "inimigo" a rejeitar e do qual é preciso se defender. A abstração da lei não faz entrar no mundo da pessoa que se quer excluir, mas cria muros invisíveis, "barreras que rompen el abrazo del hombre", como dizia um jovem. Talvez, quem faça as leis, ainda não caminhe e não pare a dialogar, a conhecer a riqueza humana, os valores dos imigrantes, que unidos aos dos nativos, podem preparar um mundo novo, onde a diversidade acolhida enriquece reciprocamente mostrando a face pluricultural de um mundo mais fraterno.

Cada dia podemos encontrar estes imigrantes pelas ruas da cidade e caminhar ao lado deles, sem perceber as angústias pelas quais estão passando. Eles são amigos que ainda não conhecemos, que nos fazem abrir as fronteiras do nosso horizonte, nos fazem reconhecer o direito de cada pessoa de ser gente com dignidade, não importando a etnia, cor ou nacionalidade, testemunhando que não há estrangeiros e sim irmãos. $\mathrm{Na}$ verdade, as migrações continuam reclamando hoje o reconhecimento, na concreta realidade cotidiana, da unidade da família humana, que fala de acolhida e solidariedade.

A Lei do Estrangeiro deveria ser modificada sendo assumida a Convenção Internacional sobre a Proteção dos Direitos dos Trabalhadores Migrantes e seus Familiares, da ONU, de dezembro de 1990, que estabelece normas de tratamento igualitário entre nacionais e migrantes e atribui direitos humanos fundamentais a todos, legais ou ilegais considerando que os trabalhadores migrantes são muito mais do que entidades econômicas ou laborais, sobretudo são pessoas humanas com outros componentes familiares, que querem viver uma vida digna e feliz, como qualquer um de nós.

\footnotetext{
"Margherita Bonassi é missionária secular scalabriniana, mestranda em sociologiaPUC/SP.
}

\begin{abstract}
"Parece-nos que repentinamente estes anos de emigração foram cancelados, parece-nos que tudo está caindo no vazio, na inutilidade..." dizia uma jovem mulher boliviana, na sua pequena moradia. Ela, o marido e as três crianças, foram obrigados a se mudar repentinamente, por medo de serem descobertos. A Polícia Federal tinha multado o marido, encontrado com o documento provisório vencido. Devia deixar o país. Mas como fazer, se depois não o deixariam entrar sem o recibo da multa paga? "Não temos dinheiro e não podemos voltar para a Bollvia, vendemos tudo lá, e aqui, se nos descobrirem... Não, nem queremos pensar nisso... Deus sabe, estamos nas mãos Dele". Ao bater na porta, logo eu tinha percebido o alívio deles ao ver que era eu... "Mas agora, aquilo que mais nos preocupa é Miguelito, o expulsaram da escola..." (Julio, 24, São Paulo, 1994).
\end{abstract}

“Sábado chegará minha esposa... quanto esperei este dia... mas agora... eu fiquei sem trabalho e sem casa... Veio uma fiscalização no serviço... um colega me avisou e eu fugi. Nem voltei para pegar o dinheiro, estou com medo. Fiquei na rua, sem saber para onde ir... Já tinha escrito para Carmen comunicando-lhe que finalmente podia vir... e eu estava contando os dias... Faz quatro anos que vivo de bicos, até faxina nas casas fiz... Achei uma vaga com outros rapazes, mas não posso levar Carmen... Faltam dois dias..." (Julio, 24; São Paulo, 1995).

"Ainda estou ilegal, não vai acreditar, eu com 12 anos de Brasil. Na anistia de 88 eu tive que viajar para o Chile... morreu meu irmão num acidente... quando voltei o prazo da anistia estava vencido. Escutei no rádio do último prazo de recadastramento dos estrangeiros... Um amigo me falou de me apresentar na Polícia, mas estou com medo, já uma vez fui multado... Dão mesmo o documento? A gente vive meio paranóico quando vejo um policial... Vivo há nove anos com Ángela. Não quis casar pelo documento, por interesse, mas agora que mesmo queremos, o cartório não aceita, é proibido com o meu visto vencido... Tenho ainda uma multa pendente, como faço? Não podemos ter filhos..." (Alfonso, chileno, 1996).

"Veio a policia na oficina de costura em que trabalhava... Nos trataram muito mal, revisaram tudo como fóssemos traficantes... Tenho que sair do Brasil, e também os outros... fomos multados todos os ilegais, seis... Também dois brasileiros trabalham conosco... Senti a dor da discriminação... não somos todos da mesma familia humana? O povo brasileiro é acolhedor, é a lei que separa as pessoas, que discrimina, por que?? Que culpa temos de ter nascido em outro lugar?" (Victor, boliviano, 1997) 